\title{
A survey of career status identity on student college
}

\author{
Kusumawati Kusuma ${ }^{* 1}$, Suwarjo Suwarjo ${ }^{2}$ \\ ${ }^{12}$ Universitas Negeri Yogyakarta, Indonesia \\ *)Corresponding author, @e-mail: baggystorybook@gmail.com
}

\begin{abstract}
One of the major concerns of students while transiting from adolescent into adulthood is the status of career identity. Good status enables teenagers to survive in increasingly competitive conditions. This study aims to determine the status of career identity found in first year students at Yogyakarta State University. The survey method was used to colled data from 500 respondents, using the scale spread. This was also used by SPSS to determine data validity and reliability. The results show that $96 \%$ of respondents in the right field are in the achievement category and $4 \%$ in the foreclosure category. While in the non-exact field $97 \%$ are in the achievement category and 3\% in the foreclosure category. Therefore, it is stated that $95 \%$ of respondents have good identity status, and are expected to survive in increasingly competitive conditions. This study contributes to literature of career identity status other contributions described.
\end{abstract}

Keywords: the establishment of career identity status, students, adolescents

How to Cite: Kusuma, K., \& Suwarjo, S. (2019). A Survey of career status identity on student college. COUNS-EDU: The International Journal of Counseling and Education, 4(1), 38-44. DOI: https://doi.org/10.23916/0020190417310

This is an open access article distributed under the Creative Commons Attribution License, which permits unrestricted use, distribution, and reproduction in any medium, provided the original work is properly cited. (C2019 by author.

\section{Introduction}

Teenagers are not separated from the development along with the indiviuals age. During the transition from adolescence to adulthood changes must be addressed, including evaluation of self-identity and confronting moral and spiritual challenges, which are common amongst teenagers. The development period add to the demands and stress faced by adolescents. For example, looking for jobs in increasingly competitive conditions, developing good relationships with others, and adapting to a technology all of which put a little pressure on teenagers (Geldard, 2009).

First-year students fall into the youth category, owing to their age which ranges from 18 to 22 years. This is usually a period when teens determine their future as seen from the career domain. The transition from adolescence to adulthood occurs in various aspects such as, confusion in work, education, college, occupation, unemployment, change of residence, romantic couples, and cultural differences from high school status to students (Howard \& Galambos, 2011). The success of adolescence will affect early adulthood, such as career satisfaction, the attainment of romantic and parenting relationships, as well as residential changes (Howard \& Galambos, 2011). Adolescents who move toward adulthood begin to individualize themselves and struggle to avoid depending on thier parents. However, at this stage adolescents lead to the formation of positive identities accompanied by problems or depression (Papalia \& Feldman, 2015).

Other possible risks are in unfavorable socioeconomic environments, drug abuse, antisocial behavior, and association with deviant groups. Macau, is a region with limited natural resources, 


\section{COUNS-EDU}

therefore, it relies on the economy of many luxury casinos. This has a negative impact on teenagers who drop out of college or even discontinue classes due to socioeconomic influences, with the view that the material and opinions of the environment are more important (Ouyang, Jin, \& Tien, 2016). The result from interviewing students in the final adolescent phase indicate a fear of responsibilities which is faced in adulthood, doubts about the ability to overcome them, and the hope of finding a more meaningful life accompanied by fear of failure (Kroger, 2015).

Changes in the social environment which occurs during adolescence also affect the increased social sensitivity in adolescent behavior (Blakemore \& Mills, 2014). This development is certainly interrelated with each other, when the process decreases, then it will be a separate record for the teenager. The fragile threat of adolescent identity, especially in the case of a career to undergo are of particular concern.

Berk defines identity as a well-organized self-concept, consisting of an individual's commitment to values, beliefs, and goals (Valentini \& Nisfiannoor, 2006). The identity structure formed for the first time in late adolescence is an important component during the life cycle (Marcia, Waterman, Matteson, Archer, \& Orlofsky, 1993). The better the structure of individual self-understanding develops, the more they are aware of the shortcomings and advantages. Conversely, if the structure of individual understanding is less developed then it will increasingly depend on external sources to self-evaluate.

Self identity is also a special experience of the self characterized by, a direct focus on oneself that aims to capture the basic purpose of self, the realization of what is true, and the authenticity of selfperception which becomes increasing long as proficiency develops. The emergence and transformation of identity may be partly explained in that respect (Moshman, 2005). Self-identity is not something unstable, but a process of reflection that continues throughout human life. Individual identity develops by passing through four identity states such as, diffusion, foreclose, moratorium, and achievement. Individuals who pass through these status will experience a variety of process crisis identity. In relation to the four statuses of identity, Marcia states that diffusion is an individual status that has never experienced crisis (exploration) or make a commitment in life (Santrock, 2014). They do not make decisions about job choice or ideology. Papalia \& Feldman (2015) adds that individuals on diffusion status do not have a high degree of seriousness in considering choices and also avoid commitment.

Starting from the tender age of a child, career development has existed since the growth and development. Many children have idealistic fantasies about what they want to become in the future. For example some fantacize on becoming a superhero, sports star and so forth. As time passes by, this set of children start thinking about less idealistic careers (Santrock, 2014). Damon (2008) states that children are not the only ones that possess career idealistic fantasies, but many adolescence today also dream about fantasy careers which may not have a relationship with reality. Adolescence who do not know what is needed to achieve their desires usually do not have someone who can help them achieve their desired career goals. Exploration, decision making, and planning play an important role in adolescence career decisions (Erik J. Porfeli \& Lee, 2012). Career development is also related to the development of adolescent identity towards adulthood (Erik J. Porfeli \& Lee, 2012). Especially in economic conditions which have tended to decline lately and are characterized by high rate of youth unemployment (Pew Research Center, 2012). In late adolescence, career decisions usually have become more serious as they explore the career possibilities they require. The late teenagers at college begin choosing majors or specialties to design what work they will carry out more specifically. Then after they complete the course or education, they begin to fully work.

Super designed a view of a wide range of career developments, which was seen as a process that included many factors (Winkel \& Hastuti, 2010). Some of such factors exist in the individual and to some extant in his or her environment, which all interact with each other and together to form the process of one's career development. As previously pointed out, achieving the identity status of teenage career late cannot be separated from the contribution of the microscope that surrounds the late adolescents. This is because many of the values and roles are adopted from micro systems around these set of people (Winkel \& Hastuti, 2010).

Some research results indicate that vocational self-image develops during physical growth and cognitive development. This takes place through observation of working adults, living experience, and the influence received from the environment. Individuals through awareness of similarities and differences between self and others eventually formed a vocational self-image. This fosters an internal impulse which 
directs a person into an area that makes it possible to achieve success and satisfaction. Therefore, one who manifests self-image in a field of office is most likely to express themselves. This will certainly raise questions relating to how the status on career identity in teenagers, especially first-year students at Yogyakarta State University. Identifying the above problems led the researchers into conducting a research that aims to determine the phenomenon of teenage career identity status in first-year students at Yogyakarta State University. The results of this study are expected to be utilized as a preventive effort in preparing teenagers who have strong stance and capable of achieving a good identity status.

\section{Method}

The survey method is used to carry out this, which is a non-experimental research technique based on interviews or questionnaires (Johnson, R. \& Christensen, 2014). In this study the researchers used a cross-sectional design survey method (compare two or more groups) which compared the interests of majors to gender (Creswell, 2012). The population consists of all first-year students aged 18-22 years or in UNY's final adolescence age consisting of 5231 people. In this study the cluster random sampling method is used because the research results showed the influence of university study interest on the status of adolescent identity (Adams \& Fitch, 1983). Yogyakarta State University has 7 faculties classified into two namely eksakta (MIPA, FIK and Engineering) and non-exact (FIP, FIS, FBS, FE). The distribution of male and female samples in the exact and non-exact plane is derived from the calculation of Krejie and Morgan tables, with a population of 5231 people, using 357 samples. Furthermore, the number of samples based on male sex (L) and female (P) of the exact and non-exact field was counted so that the sample became 500 respondents.

The research instrument used to identify career identity status data in these students is a basic theory from Marcia which divided the aspects into two, namely the high and low levels of exploration and commitment activities. These were contained in 49 item statement on a scale, using four response levels namely, very appropriate, appropriate, inappropriate, and very inappropriate. Furthermore, the scale is compiled and tested for validity and reliability using SPSS 21 software for windows, with the results represented as follows:

Table 1. Result of Research Instrument Test Career Status Identity Scale

\begin{tabular}{lll}
\hline & $\begin{array}{l}\text { Aspects of } \\
\text { Commitment }\end{array}$ & $\begin{array}{l}\text { Aspects of } \\
\text { Exploration }\end{array}$ \\
\hline $\begin{array}{l}\text { Keizer-Meyer-Olkin Exploration Measure of Sampling } \\
\begin{array}{l}\text { Adequacy (MSA) } \\
\text { Reliability Cronbach's Alpha }\end{array}\end{array}$ &, $776>0.5$ &, $812>0.5$ \\
& $\begin{array}{l}, 872>0.113 \text { (r count }>\text { rtable level sig } 5 \% \\
\text { with N 49 items) The }\end{array}$ \\
\hline
\end{tabular}

The Table above shows that all items are eligible and used for further testing. The reliability results illustrates that the calculated rhyme is greater than rtable at the level of $5 \%$, therefore, the instruments developed in this study are reliable.

\section{Results and Discussions}

Data on the status of adolescent final identity is the main data to be obtained in this study. Marcia's status theory of identity is the main reference in evaluating the identity status of teenagers, by analyzing their exploration and commitment. The level of exploration is measured by the multiplying number of late teenagers and looking for information relating to the majors they are currently in, while the level of commitment is measured by how much the late teenagers maintain their current majors. From the results of the analysis of the scale spread with a sample of 497, the data found is as follows: 
Table 2. Status Identity Career Student Eksakta

\begin{tabular}{lrr}
\hline Identity status & Number (Reponden) & Percent \\
\hline Achievement & 266 & $96 \%$ \\
Moratorium & 0 & $0 \%$ \\
Foreclosure & 10 & $4 \%$ \\
Diffusion & 0 & $0 \%$ \\
Total & & 276 respondent \\
\hline
\end{tabular}

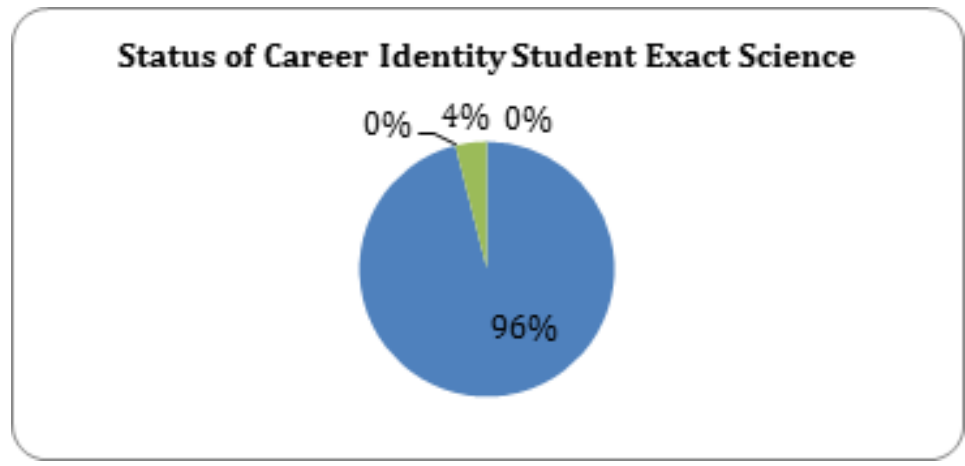

Diagram 1. Status of Career Identity Student Exact Science

Data shows the status of career identity in the late teens ie first year students on the exact sciences field. From the tables and diagrams it is known that the identity status of teenagers in exact students dominate the achievement with 266 respondents (96\%), that of foreclosure is as much as 10 respondents $(4 \%)$, and no respondents were found in the status category of moratorium and diffusion identity. While data for first year students who are in non-exact field are as follows:

Table 3. Status of Student Identity of Student Non-Exact

\begin{tabular}{lrr}
\hline Identity Status & Number (Respondent) & Percent \\
\hline Achievement & 218 & $97 \%$ \\
Moratorium & 0 & $0 \%$ \\
Foreclosure & 6 & $3 \%$ \\
Diffusion & 0 & $0 \%$ \\
Total & & 224 of respondents \\
\hline
\end{tabular}

\section{Status of Career Identity Student Non-Exact}

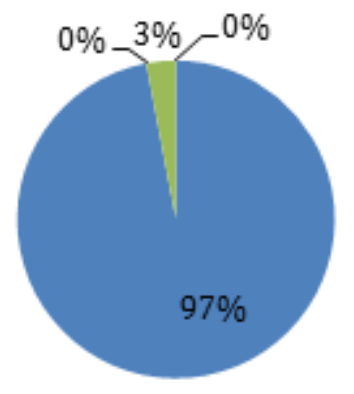

Diagram 2. Status of Career Identity Student Non-Exact 
The result obtained wasn't quite different from that of the first year students of exact sciences, and non-exact regions which comprises of 224 respondents with 218 (97\%) in the achievement category, 6 (3\% ) in the foreclosure category, and none in the of moratorium or diffusion category. The diagram gives an illustration that the state of first year students at Yogyakarta State University is on the status of career identity that achievement.

These results indicate the high level of identity status achievement in the students at Yogyakarta State University, but there are some who are in the low range therefore, they were categorized in the identity status foreclosure. Preventive efforts to overcome the obstacles faced by adolescent in achieving the achievement needs to be conducted, with a high role in the family to make the final teenagers more determined in making a choice. For those at the foreclosure stage where adolescents only accept what has been decided, the low level of exploration of the departments are undertaken into a separate task for counselors to provide assistance with diligent promotion of counseling and guidance services to be provided.

Furthermore, adolescents who are in the status of achievement identities are better able to articulate their career choices and the next step in obtaining short and long term goals. Conversely, those who are in the status of moratorium identity and diffusion are more likely to struggle with making career plans and decisions (Santrock, 2012).

Changes in identity status, especially in careers, are influenced by the development and growth of the adolescent itself, from early, to late adulthood. In the late adolescent phase individuals will achieve a higher identity status than the early adolescent phase (Meeus, van de Schoot, Keijsers, \& Branje, 2012). Many factors influence adolescent cognitive development. This is also in accordance with the research conducted by Klimstra, Hale, Raaijmakers, Branje, \& Meeus (2010) which states that adolescents experience development in exploring their deeper identities towards adulthood. In addition to cognitive development there are various other factors that contribute to the career identity status of adolescents in higher education such as the task of development that demands more, and the social environment.

Changes in the social environment which occurs around adolescents became a major factor in the development of their career identity status. Exploring self-identity can involve wider and deeper social substance (Malanchuk, Messersmith, \& Eccles, 2010). Metheny \& McWhirter (2013) results indicate that family status and support are linked to career development outcomes. In addition, other social environmental factors also come from peers (Kiuru, Koivisto, Mutanen, Vuori, \& Nurmi, 2011), the educational environment by relying on the support of college friends (Patel, Salahuddin, \& O'Brien, 2008), the climate of competence in their colleges (Reynolds \& Constantine, 2007), as well as the community environment that pressures their future (Krenke in Santrock, 2014). Therefore, the importance of interaction within and between social environments around adolescents (Duerden \& Witt, 2010), and actively involved in these sub-systems (Shaffer, 2009).

Previous research, shows the difference in identity status accounts for significant variations in student progress toward the size of academic autonomy, educational involvement and mature interpersonal relationships. Identity status also provides an overview of differences in job security and youth welfare (E. J. Porfeli \& Skorikov, 2010).

This research provides information to the reader on ways to describe the identity status of adolescents who are in the late transition category. This research is rarely carried out in Indonesia, however, it was conducted research at Yogyakarta State University. It is believed that researchers achieve career identity status with the ability to prepare and adjust the circumstances of the lectures in the university context (Berzonsky \& Kuk, 2000). This study shows that the majority of first-year students at Yogyakarta State University have career identity status which is an achievement. This means that the confidence and commitment of the chosen department at the beginning of the career gate facing the next phase has been good. The next step is to provide direction and guidance to deal with every process that will be undertaken in the future. However, students who are in the moratorium category need to be given more attention. 


\section{COUNS-EDU}

This study is limited to the ability of researchers to deepen the identity status of adolescent careers, this would appropriate interventions for students in the foreclosure category. The researchers suggested that further studies should be carried out to explore the right interventions and provide counseling services to students within the foreclosure category.

\section{Conclusions}

Research has concluded that there are $96 \%$ respondents are in the exact field and $97 \%$ in the nonexact fields are in the achievement category whereas, $4 \%$ in the exact field and 3\% in the non-exact are in the foreclosure category. This indicates that in the achievement category most of the adolescents entering the college, have the level of exploration and commitment that align and always appear on every career information search, making teens establish themselves against the choice. While teenagers with foreclosure categories indicate lack of exploration levels, so that these adolescents tend to only accept what has been there, without finding out more about it. Teenagers with a strong future orientation, will perform better in future career planning (Negru-Subtirica \& Pop, 2016). The findings of this study are expected to be a reference to provide assistance to adolescents in order to maintain the status of career identity and provide an overview of efforts that must be carried out in improving their identity status. This allows teenagers to have a sense of meaning in their lives, and career, while strengthening both (Dik, Sargent, \& Steger, 2008). The sense of meaningfulness of adolescents in their careers influences the choice of majors that will be undertaken. Zafar (2013) explains that women are less likely to choose majors in engineering because it is believed that they will not enjoy its lectures. This may affect the development of their career identity status. In addition (Perez et al., 2014) mentioned the development of exploration identity positively associated with students' beliefs about their competence. Therefore, the belief in a career choice will affect the developmental pattern of adolescent career identity status in this case the student scope.

The findings of this study could be a start for further research, where the current life context varies more in the possibility of career selection as a teenager. Education is important especially in the context of Indonesia, as teenagers now face an era of globalization, where career competition is the main topic of the day. However, further investigators also need to pay more attention to the context of the microsystem environment around adolescents.

\section{References}

Adams, G. R., \& Fitch, S. a. (1983). Psychological environments of university departments: Effects on college students' identity status and ego stage development. Journal of Personality and Social Psychology, 44(6), 1266-1275. https://doi.org/10.1037/0022-3514.44.6.1266

Berzonsky, M. D., \& Kuk, L. S. (2000). Identity status, identity processing style, and the transition to University. Journal of Adolescent Research, 15(1), 81-98. https://doi.org/10.1177/0743558400151005

Blakemore, S.-J., \& Mills, K. L. (2014). Is adolescence a sensitive period for sociocultural processing? Annual Review of Psychology, 65(1), 187-207. https://doi.org/10.1146/annurev-psych-010213115202

Creswell, J. W. (2012). Educational research: Planning, conducting, and evaluating quantitative and qualitative research. Educational Research (Vol. 4). https://doi.org/10.1017/CBO9781107415324.004

Damon, W. (2008). The path to purpose: Helping our children find their calling in life. New York: The Free Press.

Dik, B. J., Sargent, A. M., \& Steger, M. F. (2008). Career Development Strivings. Journal of Career Development, 35(1), 23-41. https://doi.org/10.1177/0894845308317934

Duerden, M. D., \& Witt, P. A. (2010). An Ecological Systems Theory Perspective on Youth Programming. Journal of Park and Recreation Administration Summer, 28(2), 108-120.

Geldard, K. (2009). Konseling remaja: intervensi praktis bagi remaja berisiko. (K. Geldard, Ed.). Yogyakarta: Pustaka Pelajar.

Howard, A. L., \& Galambos, N. L. (2011). Transitions to adulthood. Encyclopedia of Adolescence, 1.

Johnson, R., B., \& Christensen, L. (2014). Educational research: qualitative, quantitative, and mixed method. (Fifth). US Amerika: Sage.

Kiuru, N., Koivisto, P., Mutanen, P., Vuori, J., \& Nurmi, J.-E. (2011). How Do Efforts to Enhance Career Preparation Affect Peer Groups? Journal of Research on Adolescence, 21(3), 677-690. 
https://doi.org/10.1111/j.1532-7795.2010.00701.x

Klimstra, T. A., Hale, W. W., Raaijmakers, Q. A. W., Branje, S. J. T., \& Meeus, W. H. H. (2010). Identity formation in adolescence: Change or stability? Journal of Youth and Adolescence, 39, 150162. https://doi.org/10.1007/s10964-009-9401-4

Kroger, J. (2015). Identity in Childhood and Adolescence. International Encyclopedia of the Social \& Behavioral Sciences (Second Edi, Vol. 11). Elsevier. https://doi.org/10.1016/B978-0-08-0970868.34015-6

Malanchuk, O., Messersmith, E. E., \& Eccles, J. S. (2010). The ontogeny of career identities in adolescence. New Directions for Child and Adolescent Development, 2010(130), 97-110. https://doi.org/10.1002/cd.284

Marcia, J. E., Waterman, A. S., Matteson, D. R., Archer, S. L., \& Orlofsky, J. L. (1993). Ego Identity: A Handbook for Psychosocial Research. https://doi.org/10.1007/978-1-4613-8330-7

Meeus, W., van de Schoot, R., Keijsers, L., \& Branje, S. (2012). Identity Statuses as Developmental Trajectories: A Five-Wave Longitudinal Study in Early-to-Middle and Middle-to-Late Adolescents. Journal of Youth and Adolescence, 41(8), 1008-1021. https://doi.org/10.1007/s10964-011-9730-y

Metheny, J., \& McWhirter, E. H. (2013). Contributions of Social Status and Family Support to College Students' Career Decision Self-Efficacy and Outcome Expectations. Journal of Career Assessment, 21(3), 378-394. https://doi.org/10.1177/1069072712475164

Moshman, D. (2005). Adolescent Psychological Development. Juvenile psychiatry and the law. https://doi.org/10.1542/pir.29-5-161

Negru-Subtirica, O., \& Pop, E. I. (2016). Longitudinal links between career adaptability and academic achievement in adolescence. Journal of Vocational Behavior, 93(37), 163-170. https://doi.org/10.1016/j.jvb.2016.02.006

Ouyang, B., Jin, S. R., \& Tien, H. L. S. (2016). Vocational Identity Formation of College Students in Macau. Career Development Quarterly, 64(3), 244-258. https://doi.org/10.1002/cdq.12058

Papalia, D. E., \& Feldman, R. D. (2015). Menyelami perkembangan manusia (Edisi 12). Jakarta: Salemba Humanika.

Patel, S. G., Salahuddin, N. M., \& O'Brien, K. M. (2008). Career decision-making self-efficacy of Vietnamese adolescents: the role of acculturation, social support, socioeconomic status, and racism. Journal of Career Development, 34(3), 218-240. https://doi.org/10.1177/0894845307308488

Perez, Tony, Cromley, Jennifer G., Kaplan, \& Avi. (2014). PsycNET. Retrieved July 1, 2018, from http://psycnet.apa.org/buy/2013-29639-001

Porfeli, E. J., \& Lee, B. (2012). Career development during childhood and adolescence. New Directions for Youth Development, 2012(134), 11-22. https://doi.org/10.1002/yd.20011

Porfeli, E. J., \& Skorikov, V. B. (2010). Specific and Diversive Career Exploration During Late Adolescence. Journal of Career Assessment, 18(1), 46-58. https://doi.org/10.1177/1069072709340528

Reynolds, A. L., \& Constantine, M. G. (2007). Cultural adjustment difficulties and career development of International college students. Journal of Career Assessment, 15(3), 338-350. https://doi.org/10.1177/1069072707301218

Santrock, J. W. (2014). Adolescence (FIFTEENTH). New York: McGraw-Hill Education.

Shaffer, D. R. (2009). Social and personality development (Sixth). USA: ICC Macmillan Inc.

Valentini, V., \& Nisfiannoor, M. (2006). Identity achievement dengan intimacy pada remaja SMA. Jurnal Provitae, 2(1), 1-12.

Winkel, W. ., \& Hastuti, M. M. S. (2010). Bimbingan dan konseling di institusi pendidikan. Yogyakarta: Media Abadi.

Zafar, B. (2013). College Major Choice and the Gender Gap. Journal of Human Resources, 48(3), 545595. https://doi.org/10.3368/jhr.48.3.545 